EDITOR's NoTE:

The following paper was presented at a seminar at this bank by Harry G. Johnson, Professor of Economics at both the London School of Economics and Political Science and The University of Chicago. Professor Johnson prepared the paper in March 1969 for The Institute of Economic Affairs, London, England. Together with a paper by John E. Nash, it has been published by The Institute of Economic Affairs as "UK and Floating Exchanges," Hobart Papers No. 46, London, England, May 1969.

\title{
The Case For Flexible Exchange Rates, 1969*
}

\author{
by HARRY G. JOHNSON
}

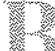
- y "flexible exchange rates" is meant rates of foreign exchange that are determined daily in the markets for foreign exchange by the forces of demand and supply, without restrictions imposed by governmental policy on the extent to which rates can move. Flexible exchange rates are thus to be distinguished from the present system (the International Monetary Fund system) of international monetary organization, under which countries commit themselves to maintain the foreign values of their currencies within a narrow margin of a fixed par value by acting as residual buyers or sellers of currency in the foreign exchange market, subject to the possibility of effecting a change in the par value itself in case of "fundamental disequilibrium." This system is frequently described as the "adjustable peg" system. Flexible exchange rates should also be distinguished from a spectral system frequently conjured up by opponents of rate flexibility - wildly fluctuating or

\footnotetext{
The title acknowledges the indebtedness of all serious writers on this subject to Milton Friedman's modern classic essay "The Case for Flexible Exchange Rates," written in 1950, and published in 1953 (M. Friedman, Essays in Pasitive Economics (Chicago: University of Chicago Press, 1953), pp. 157-203, abridged in R. E. Caves and H. G. Johnson (eds.), Readings in International Economics (Homewood, Illinois: Richard D. Irwin, for the American Econonic Association, 1968), chapter 25 , pp. $413-37$.
}

"unstable" exchange rates. The freedom of rates to move in response to market forces does not imply that they will in fact move significantly or erratically; they will do so only if the underlying forces governing demand and supply are themselves erratic - and in that case any international monetary system would be in serious difficulty. Finally, Hexible exchange rates do not necessarily imply that the national monetary authorities must refrain from any intervention in the exchange markets; whether they should intervene or not depends on whether the authorities are likely to be more or less intelligent and efficient speculators than the private speculators in foreign exchange - a matter on which empirical judgment is frequently inseparable from fundamental political attitudes.

The fundamental argument for flexible exchange rates is that they would allow countries autonomy with respect to their use of monetary, fiscal, and other policy instruments, consistent with the maintenance of whatever degree of freedom in international transactions they chose to allow their citizens, by automatically ensuring the preservation of external equilibrium. Since in the absence of balance-of-payments reasons for interfering in international trade and payments, and given autonomy of domestic policy, there 
is an overwhelmingly strong case for the maximum possible freedom of international transactions to permit exploitation of the economies of international specialization and division of labour, the argument for flexible exchange rates can be put more strongly still: flexible exchange rates are essential to the preservation of national autonomy and independence consistent with efficient organization and development of the world economy.

The case for flexible exchange rates on these grounds has been understood and propounded by economists since the work of Keynes and others on the monetary disturbances that followed the First World War. Yet that case is consistently ridiculed, if not dismissed out of hand, by "practical" men concerned with international monetary affairs, and there is a strong revealed preference for the fixed exchange rate system. For this one might suggest two reasons: First, successful men of affairs are successful because they understand and can work with the intricacies of the prevalent fixed rate system, but being "practical" find it almost impossible to conceive how a hypothetical alternative system would, or even could, work in practice; Second, the fixed exchange rate system gives considerable prestige and, more important, political power over national governments to the central bankers entrusted with managing the system; power which they naturally credit themselves with exercising more "responsibly" than the politicians would do, and which they naturally resist surrendering. Consequently, public interest in and discussion of flexible exchange rates generally appears only when the fixed rate system is obviously under serious strain and the capacity of the central bankers and other responsible officials to avoid a crisis is losing credibility.

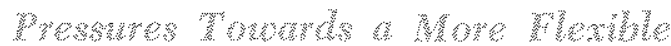

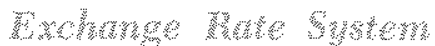

The present period has this character, from two points of view. On the one hand, from the point of view of the international economy, the long-sustained sterling crisis that culminated in the devaluation of November 1967, the speculative doubts about the dollar that culminated in the gold crisis of March 1968, and the franc-mark crisis that was left unresolved by the Bonn meeting of November 1968 and still hangs over the system, have all emphasized a serious defect of the present international monetary system. ${ }^{1}$

The exchange speculation in favor of the Deutsche Mark in early May 1969 is only the latest example of instability in the present fixed exchange rate system.
This is the lack of an adequate adjustment mechanism - a mechanism for adjusting international imbalances of payments towards equilibrium sufficiently rapidly as not to put intolerable strains on the willingness of the central banks to supplement existing international reserves with additional credits, while not requiring countries to deflate or inflate their economies beyond politically tolerable limits. The obviously available mechanism is greater automatic flexibility of exchange rates (as distinct from adjustments of the "pegs"). Consequently, there has been a rapidly growing interest in techniques for achieving greater automatic flexibility while retaining the form and assumed advantages of a fixed rate system. The chief contenders in this connection are the "band" proposal, under which the permitted range of exchange rate variation around parity would be widened from the present one per cent or less to, say, five per cent each way, and the so-called "crawling peg" proposal, under which the parity for any day would be determined by an average of past rates established in the market. The actual rate each day could diverge from the parity within the present or a widened band, and the parity would thus crawl in the direction in which a fully flexible rate would move more rapidly.

Either of these proposals, if adopted, would constitute a move towards a flexible rate system for the world economy as a whole. On the other hand, from the point of view of the British economy alone, there has been growing interest in the possibility of a floating rate for the pound. This interest has been prompted by the shock of devaluation, doubts about whether the devaluation was sufficient or may need to be repeated, resentment of the increasing subordination of domestic policy to international requirements since 1964, and general discontent with the policies into which the commitment to maintain a fixed exchange rate has driven stuccessive Governments - "stop-go policies," higher average unemploy" ment policies, incomes policies, and a host of other domestic and international interventions.

From both the international and the purely domestic point of view, therefore, it is apposite to reexamine the case for flexible exchange rates. That is the purpose of this essay. For reasons of space, the argument will be conducted at a general level of principle, with minimum attention to technical details and complexities. It is convenient to begin with the case for fixed exchange rates; this case has to be constructed, since little reasoned defense of it has been produced beyond the fact that it exists and 
functions after a fashion, and the contention that any change would be for the worse. Consideration of the case for fixed rates leads into the contrary case for flexible rates. Certain common objections to flexible rates are then discussed. Finally, some comments are offered on the specific questions mentioned above, of providing for greater rate flexibility in the framework of the IMF system and of floating the pound by itself.

\section{The Case for Fixed Exchange Rates}

A reasoned case for fixed international rates of exchange must run from analogy with the case for a common national currency, since the effect of fixing the rate at which one currency can be converted into another is, subject to qualifications to be discussed later, to establish the equivalent of a single currency for those countries of the world economy adhering to fixed exchange rates. The advantages of a single currency within a nation's frontiers are, broadly, that it simplifies the profit-maximizing computations of producers and traders, facilitates competition among producers located in different parts of the country, and promotes the integration of the economy into a connected series of markets, these markets including both the markets for products and the markets for the factors of production (capital and labour). The argument for fixed exchange rates, by analogy, is that they will similarly encourage the integration of the national markets that compose the world economy into an international network of connected markets, with similarly beneficial effects on economic efficiency and growth. In other words, the case for fixed rates is part of a more general argument for national economic policies conducive to international economic integration.

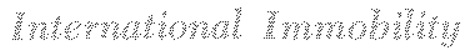

The argument by analogy with the domestic economy, however, is seriously defective for several reasons. In the first place, in the domestic economy the factors of production as well as goods and services are free to move throughout the market area. In the international economy the movement of labour is certainly subject to serious barriers created by national immigration policies (and in some cases restraints on emigration as well), and the freedom of movement of capital is also restricted by barriers created by national laws. The freedom of movement of goods is also restricted by tariffs and other barriers to trade. It is true that there are certain kinds of artificial barriers to the movement of goods and factors internally to a national economy (apart from natural barriers created by distance and cultural differences) created sometimes by national policy (e.g., regional development policies) and sometimes by the existence of state or provincial governments with protective policies of their own. But these are probably negligible by comparison with the barriers to the international mobility of goods and factors of production. The existence of these barriers means that the fixed exchange rate system does not really establish the equivalent of a single international money, in the sense of a currency whose purchasing power and whose usefulness tends to equality throughout the market area. A more important point, to be discussed later, is that if the fixity of exchange rates is maintained, not by appropriate adjustments of the relative purchasing power of the various national currencies, but by variations in the national barriers to trade and payments, it is in contradiction with the basic argument for fixed rates as a means of attaining the advantages internationally that are provided domestically by a single currency.

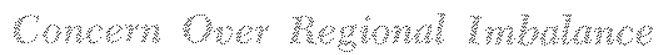

In the second place, as is well known from the prevalence of regional development policies in the various countries, acceptance of a single currency and its implications is not necessarily beneficial to particular regions within a nation. The pressures of competition in the product and factor markets facilitated by the common currency instead frequently result in prolonged regional distress, in spite of the apparent full freedom of labour and capital to migrate to more remunerative locations. On the national scale, the solution usually applied, rightly or wrongly, is to relieve regional distress by transfers from the rest of the country, effected through the central government. On the international scale, the probability of regional (national in this context) distress is substantially greater because of the barriers to both factors and goods mobility mentioned previously; yet there is no international government, nor any effective substitute through international co-operation, to compensate and assist nations or regions of nations suffering through the effects of economic change occurring in the enviromment of a single currency. (It should be noted that existing arrangements for financing balance-ofpayments deficits by credit from the surplus countries in no sense fulfill this function, since deficits and surpluses do not necessarily reflect respectively distress in the relevant sense, and its absence.) 


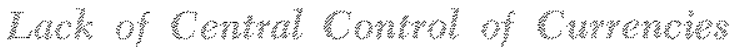

Thirdly, the beneficent effects of a single national currency on economic integration and growth depend on the maintenance of reasonable stability of its real value; the adjective "reasonable" is meant to allow for mild inflationary or deflationary trends of prices over time. Stability in turn is provided under contemporary institutional arrangements through centralization of control of the money supply and monetary conditions in the hands of the central bank, which is responsible for using its powers of control for this purpose. (Formerly, it was provided by the use of precious metals, the quantity of which normally changed very slowly.) The system of fixed rates of international exchange, in contrast to a single national money, provides no centralized control of the overall quantity of international money and international monetary conditions. Under the ideal old-fashioned gold standard, in theory at least, overall international monetary control was exercised automatically by the available quantity of monetary gold and its rate of growth, neither of which could be readily influenced by national governments, operating on national money supplies through the obligation incumbent on each country to maintain a gold reserve adequate to guarantee the convertibility of its currency under all circumstances at the fixed exchange rate. That system has come to be regarded as barbarous, because it required domestic employment objectives to be subordinated to the requirements of international balance; and nations have come to insist on their right to use interventions in international trade and payments, and in the last resort to devalue their currencies, rather than proceed farther than they find politically tolerable with deflationary adjustment policies.

The result is that the automatic mechanisms of overall monetary control in the international system implicit in the gold standard have been abandoned, without those mechanisms being replaced by a discretionary mechanism of international control comparable to the national central bank in the domestic economic system, to the dictates of which the national central banks, as providers of the currency of the "regions" of the international economy, are obliged to conform. Instead, what control remains is the outcome on the one hand of the jostling among surplus and deficit countries, each of which has appreciable discretion with respect to how far it will accept or evade pressures on its domestic policies mediated through pressures on its balance of payments, and on the other hand of the ability of the system as a system to free itself from the remnants of the constraint formerly exercised by gold as the ultimate international reserve, by using national currencies and various kinds of international credit arrangements as substitutes for gold in international reserves.

In consequence, the present international monetary system of fixed exchange rates fails to conform to the analogy with a single national currency in two important respects. Regions of the system are able to resist the integrative pressures of the single currency by varying the barriers to international transactions and hence the usefulness of the local variant of that currency, and in the last resort by changing the terms of conversion of the local variant into other variants; moreover, they have reason to do so in the absence of an international mechanism for compensating excessively distressed regions and a mechanism for providing centralized and responsible control of overall monetary conditions. Second, in contrast to a national monetary system, there is no responsible centralized institutional arrangement for monetary control of the system.

This latter point can be rephrased in terms of the commonly held belief that the fixed rate system exercises "discipline" over the nations involved in it, and prevents them from pursuing "irresponsible" domestic policies. This belief might have been tenable with respect to the historical gold standard, under which nations were permanently committed to maintaining their exchange rates and had not yet developed the battery of interventions in trade and payments that are now commonly employed. But it is a myth when nations have the option of evading discipline by using interventions or devaluation. It becomes an even more pernicious myth when it is recognized that abiding by the discipline may entail hardships for the nation that the nation will not tolerate being applied to particular regions, within itself, but will attempt to relieve by interregional transfer payments; and that the discipline is not discipline to conform to rational and internationally accepted principles of good behavior, but discipline to conform to the average of what other nations are seeking to get away with. Specifically, there might be something to be said for an international monetary system that disciplined individual nations into conducting their policies so as to achieve price stability and permit liberal international economic policies. But there is little to be said for a system that on the one hand obliges nations to accept whatever rate of world price 
inflation or deflation emerges from the policies of the other nations in the world economy, and on the other hand obliges or permits them to employ whatever policies of intervention in international trade and payments are considered by themselves and their neighbours not to infringe the letter of the rules of international liberalism.

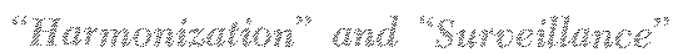

The defenders of the present fixed rate system, if pressed, will generally accept these points but argue the need for a solution along two complementary lines: "harmonization" of national economic policies in accordance with the requirements of a single world currency system, and progressive evolution towards international control of the growth of international liquidity combined with "surveillance" of national economic policies. The problem with both is that they demand a surrender of national sovereignty in domestic economic policy which countries have shown themselves extremely reluctant to accept. The reasons for this have already been mentioned; the most important are that there is no international mechanism for compensating those who suffer from adhering to the rules of the single currency game, and that the nations differ sharply in their views on priorities among policy objectives, most notably on the relative undesirability of unemployment on the one hand and price inflation on the other. The main argument for flexible exchange rates at the present time is that they would make this surrender of sovereignty unnecessary, while at the same time making unnecessary the progressive extension of interventions in international trade and payments that failure to resolve this issue necessarily entails.

The case for fixed exchange rates, while seriously defective as a defense of the present system of international monetary organization, does have one important implication for the case for flexible exchange rates. One is accustomed to thinking of national moneys in terms of the currencies of the major countries, which currencies derive their usefulness from the great diversity of goods, services and assets available in the national economy, into which they can be directly converted. But in the contemporary world there are many small and relatively narrowly specialized countries, whose national currencies lack usefulness in this sense, but instead derive their usefulness from their rigid convertibility at a fixed price into the currency of some major country with which the small country trades extensively or on which it depends for capital for investment. For such coun- tries, the advantages of rigid convertibility in giving the currency usefulness and facilitating international trade and investment outweigh the relatively small advantages that might be derived from exchange rate flexibility. (In a banana republic, for example, the currency will be more useful if it is stable in terms of command over foreign goods than if it is stable in terms of command over bananas; and exchange rate flexibility would give little scope for autonomous domestic policy.) These countries, which probably constitute a substantial numerical majority of existing countries, would therefore probably choose, if given a free choice, to keep the value of their currency pegged to that of some major country or currency bloc. In other words, the case for flexible exchange rates is a case for flexibility of rates among: the currencies of countries that are large enough to have a currency whose usefulness derives primarily from its domestic purchasing power, and for which significant autonomy of domestic policy is both possible and desired.

\section{The Case For Flexible Exchange Rates}

The case for flexible exchange rates derives fundamentally from the laws of demand and supply - in particular, from the principle that, left to itself, the competitive market will establish the price that equates quantity demanded with quantity supplied and hence clears the market. If the price rises temporarily above the competitive level, an excess of quantity supplied over quantity demanded will drive it back downwards to the equilibrium level; conversely, if the price falls temporarily below the competitive level, an excess of quantity demanded over quantity supplied will force the price upwards towards the equilibrium level. Application of this principle to governmental efforts to control or to support particular prices indicates that, unless the price happens to be fixed at the equilibrium level - in which case governmental intervention is superfluous - such efforts will predictably generate economic problems. If the price is fixed above the equilibritum level, the government will be faced with the necessity of absorbing a surplus of production over consumption. To solve this problem, it will eventually have to either reduce its support price, or devise ways either of limiting production (through quotas, taxes, etc.) or of increasing consumption (through propaganda, or distribution of surpluses on concessionary terms). If the price is fixed below the equilibrium level, the government will be faced with the necessity of meeting the excess of consumption over production out of 
its own stocks. Since these must be limited in extent, it must eventually either raise its control price, or devise ways either to limit consumption by rationing, or reduce the costs of production (e.g., by producer subsidies, or by investments in increasing productivity).

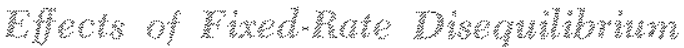

Exactly the same problems arise when the government chooses to fix the price of foreign exchange in terms of the national currency, and for one reason or another that price ceases to correspond to the equilibrium price. If that price is too high, i.e., if the domestic currency is undervalued, a balance-of-payments surplus develops and the country is obliged to accumulate foreign exchange. If this accumulation is unwelcome, the government's alternatives are to restrict exports and encourage imports either by aIlowing or promoting domestic inflation (which in a sense subsidizes imports and taxes exports) or by imposing increased taxes or controls on exports and reducing taxes or controls on imports; or to appreciate its currency to the equilibrium level. If the price of foreign exchange is too low, the domestic currency being overvalued, a balance-of-payments deficit develops and the country is obliged to run down its stocks of foreign exchange and borrow from other countries. Since its ability to do this is necessarily limited, it ultimately has to choose among the following alternatives: imposing restrictions on imports and/ or promoting exports (including imports and exports of assets, i.e., control of international capital movements); deflating the economy to reduce the demand for imports and increase the supply of exports; deflating the economy to restrain wages and prices and/or attempting to control wages and prices directly, in order to make exports more and imports less profitable; and devaluing the currency.

In either event, a deliberate choice is necessary among alternatives which are unpleasant for various reasons. Hence the choice is likely to be deferred until the disequilibrium has reached crisis proportions; and decisions taken under crisis conditions are both unlikely to be carefully thought out, and likely to have seriously disruptive economic effects.

All of this would be unnecessary if, instead of taking a view on what the value of the currency in terms of foreign exchange should be, and being therefore obliged to defend this view by its policies or in the last resort surrender it, the govemment were to allow the price of foreign exchange to be determined by the interplay of demand and supply in the foreign exchange market. A freely flexible exchange rate would tend to remain constant so long as underlying economic conditions (including governmental policies) remained constant; random deviations from the equilibrium level would be limited by the activities of private speculators, who would step in to buy foreign exchange when its price fell (the currency appreciated in terms of currencies) and to sell it when its price rose (the currency depreciated in terms of foreign currencies).

On the other hand, if economic changes or policy changes occurred that under a fixed exchange rate would produce a balance-of-payments surplus or deficit, and ultimately a need for policy changes, the flexible exchange rate would gradually either appreciate or depreciate as required to preserve equilibrium. The movement of the rate would be facilitated and smoothed by the actions of private speculators, on the basis of their reading of current and prospective economic and policy developments. If the government regarded the trend of the exchange rate as undesirable, it could take counter-active measures in the form of inflationary or deflationary policies. It would never be forced to take such measures by a balance-ol-payments crisis and the pressure of foreign opinion, contrary to its own policy objectives. The balance-of-payments rationale for interventions in international trade and capital movements, and for such substitutes for exchange rate change as changes in border tax adjustments or the imposition of futile "incomes policies," would disappear.

If the government had reason to believe that private speculators were not performing efficiently their function of stabilizing the exchange market and smoothing the movement of the rate over time, or that their speculations were based on faulty information or prediction, it could establish its own agency for speculation, in the form of an exchange stabilization fund. This possibility, however, raises the questions of whether an official agency risking the public's money is likely to be a smarter speculator than private individuals risking their own money, whether if the assumed superiority of official speculation rests on access to inside information it would not be preferable to publish the information for the benefit of the public rather than use it to make profits for the agency at the expense of unnecessarily ill-informed private citizens, and whether such an agency would in fact confine itself to stabilizing speculation or would try to enforce an official view of what the exchange rate should be - that is, whether the agency would 
not retrogress into de facto restoration of the adjustable peg system.

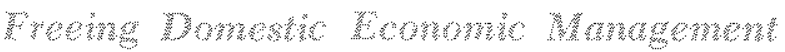

The adoption of flexible exchange rates would have the great advantage of freeing governments to use their instruments of domestic policy for the pursuit of domestic objectives, while at the same time removing the pressures to intervene in international trade and payments for balance-of-payments reasons. Both of these advantages are important in contemporary circumstances. On the one hand, there exists a great rift between nations like the United Kingdom and the United States, which are anxious to maintain high levels of employment and are prepared to pay a price for it in terms of domestic inflation, and other nations, notably Western Germany, which are strongly adverse to inflation. Under the present fixed exchange rate system, these nations are pitched against each other in a battle over the rate of inflation which is to prevail in the world economy, since the fixed rate system diffuses that rate of inflation to all the countries involved in it. Flexible rates would allow each country to pursue the mixture of unemployment and price trend objectives it prefers, consistent with international equilibrium, equilibrium being secured by appreciation of the currencies of "price stability" countries relative to the currencies of "full employment" countries.

On the other hand, the maximum possible freedom of trade is not only desirable for the prosperity and growth of the major developed countries, but essential for the integration of the developing countries into the world economy and the promotion of efficient economic development of those countries. While the postwar period has been characterized by the progressive reduction of the conventional barriers to international trade and payments - tariffs and quotas, inconvertibility and exchange controls - the recurrent balance-of-payments and international monetary crises under the fixed rates system have fostered the erection of barriers to international economic integration in new forms - aid-tying, preferential governmental procurement policies, controls on direct and portfolio international investment - which are in many ways more subtly damaging to efficiency and growth than the conventional barriers.

The removal of the balance-of-payments motive for restrictions on international trade and payments is an important positive contribution that the adoption of flexible exchange rates could make to the achievement of the liberal objective of an integrated inter- national economy, which must be set against any additional barriers to international commerce and finance, in the form of increased uncertainty, that might follow from the adoption of flexible exchange rates. That such additional uncertainty would be so great as to seriously reduce the flows of international trade and investment is one of the objections to flexible rates to be discussed in the next section.

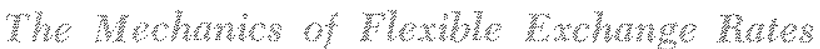

At this point, it is sufficient to make the following observations. First, as pointed out in the preceding section, under a flexible rate system most countries would probably peg their currencies to one or another major currency, so that much international trade and investment would in fact be conducted under fixed rate conditions, and uncertainty would attach only to changes in the exchange rates among a few major currencies or currency blocs (most probably, a U.S. dollar bloc, a European bloc, and sterling, though possibly sterling might be included in one of the other blocs). For the same reason-because few blocs would imply that their economic domains would be large and diversified - the exchange rates between the flexible currencies would be likely to change rather slowly and steadily. This would mean that traders and investors would be able normally to predict the domestic value of their foreign currency proceeds without much difficulty.

But, secondly, traders would be able to hedge foreign receipts or payments through the forward exchange markets, if they wished to avoid uncertainty; if there were a demand for more extensive forward market and hedging facilities than now exist, the competitive profit motive would bring them into existence.

Third, for longer-range transactions, the economics of the situation would provide a substantial amount of automatic hedging, through the fact that long-run trends towards appreciation or depreciation of a currency are likely to be dominated by divergence of the trend of prices inside the currency area from the trend of prices elsewhere. For direct foreign investments, for example, any loss of value of foreign currency earnings in terms of domestic currency due to depreciation of the foreign currency is likely to be roughly balanced by an increase in the amount of such earnings consequent on the relative inflation assom ciated with the depreciation. Similarly, if a particular country is undergoing steady inflation and its currency is depreciating steadily in consequence, money interest 
rates there are likely to rise sufficiently to compensate domestic investors for the inflation, and hence sufficiently to compensate foreign portfolio investors for their losses from the depreciation.

Finally, it should be noted that the same sort of political and economic developments that would impose unexpected losses on traders and investors through depreciation under a flexible exchange rate system, would equally impose losses in the form of devaluation, or the imposition of restrictions on trade and capital movements, under the present fixed rate system.

\section{The Case Against Flexible Exchange Rates}

The case against flexible exchange rates, like the case for fixed exchange rates, is rarely if ever stated in a reasoned fashion. Instead, it typically consists of a series of unfounded assertions and allegations, which derive their plausibility from two fundamentally irrelevant facts. The first is that, in the modern European economic history with which most people are familiar, flexible exchange rates are associated either with the acute monetary disorders that followed the First World War, or with the collapse of the internam tional monetary system in the 1930's; instead of being credited with their capacity to function when the fixed exchange rate system could not, they are debited with the disorders of national economic policies that made the fixed exchange rate system unworkable or led to its collapse. The second, and more important at this historical distance from the disastrous experiences just mentioned, is that most people are accustomed to the fixed exchange rate system, and are prone to assume without thinking that a flexible rate system would simply display in an exaggerated fashion the worst features of the present fixed rate system, rather than remedy them.

The historical record is too large a topic to be discussed adequately in a brief essay. Suffice it to say that the interwar European experience was clouded by the strong belief, based on pre-First World War conditions, that fixed exchange rates at historical parity values constituted a natural order of things to which governments would seek eventually to return, and that scholarly interpretation of that experience leaned excessively and unjustifiably towards endorsement of the official view that any private speculation on the exchanges based on distrust of the ability of the authorities to hold an established parity under changing circumstances was necessarily "destabilizing" and anti-social. It should further be remarked that Etropean interwar experience does not constitute the whole of the historical record, and that both previously (as in the case of the United States dollar from 1862 to 1879) and subsequently (as in the case of the Canadian dollar from 1950 to 1962) there have been cases of a major trading country maintaining a flexible exchange rate without any of the disastrous consequences commonly forecast by the opponents of flexible rates.

The penchant for attributing to the flexible rate system the problems of the fixed rate system can be illustrated by a closer examination of some of the arguments commonly advanced against floating exchange rates, most of which allege either that flexible rates will seriously increase uncertainty in international transactions, or that they will foster inflation.

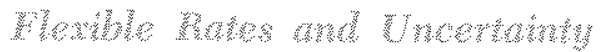

Instability of the Exchange Rate - One of the common arguments under the heading of uncertainty is that flexible rates would be extremely unstable rates, jumping wildly about from day to day. This allegation ignores the crucial point that a rate that is free to

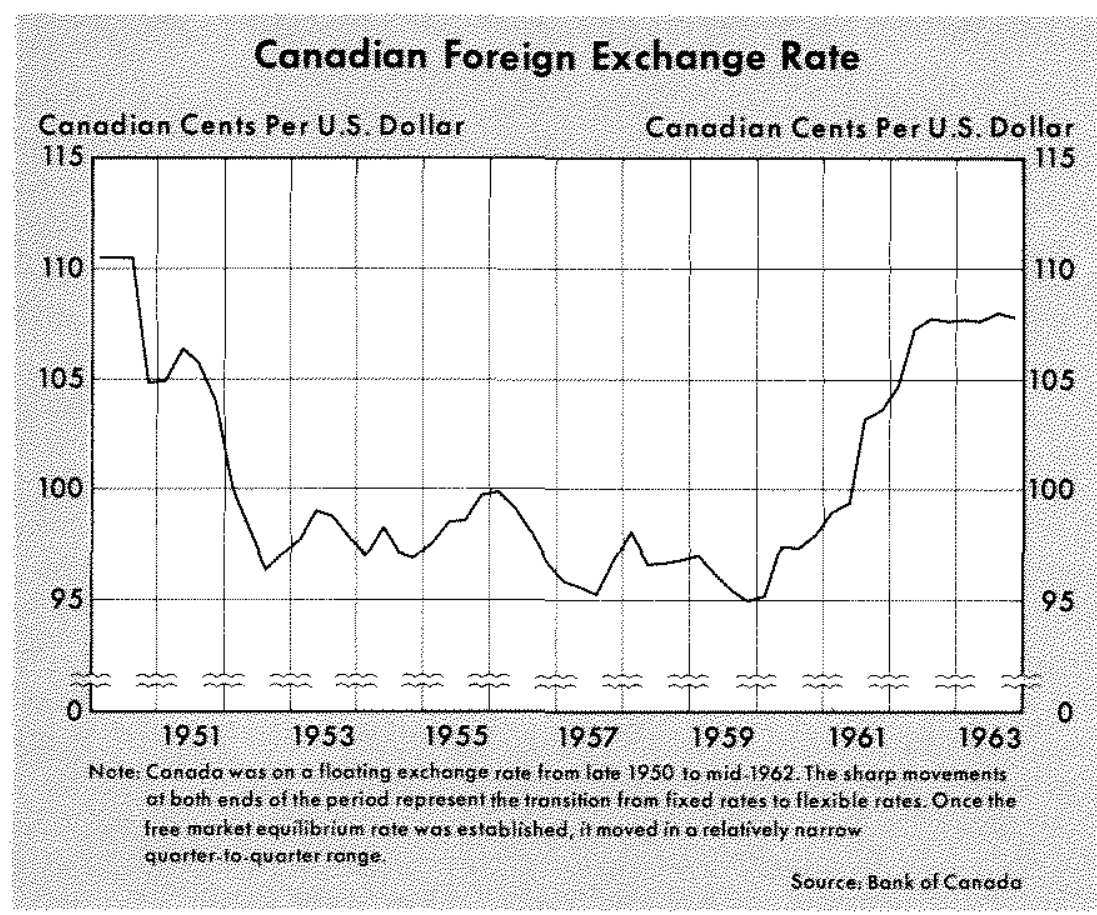


move under the influence of changes in demand and supply is not forced to move erratically, but will instead move only in response to such changes in demand and supply - including changes induced by changes in governmental policies - and normally will move only slowly and fairly predictably. Abnormally rapid and erratic movements will occur only in response to sharp and unexpected changes in circumstances; and such changes in a fixed exchange rate system would produce equally or more uncertaintycreating policy changes in the form of devaluation, deflation, or the imposition of new controls on trade and payments. The fallacy of this argument lies in its assumption that exchange rate changes occur exogenously and without apparent economic reason; that assumption reflects the mentality of the fixed rate system, in which the exchange rate is held fixed by official intervention in the face of demand and supply pressures for change, and occasionally changed arbitrarily and at one stroke by governmental decisions whose timing and magnitude is a matter of severe uncertainty.

Reduction of Foreign Trade - A related argument is that uncertainty about the domestic currency equivalent of foreign receipts or payments would seriously inhibit international transactions of all kinds. As argued in the preceding section, trends in exchange rates should normally be fairly slow and predictable, and their causes such as to provide more or less automatic compensation to traders and investors. Moreover, traders averse to uncertainty would be able to hedge their transactions through forward exchange markets, which would, if necessary, develop in response to demand. It is commonly argued at present, by foreign exchange dealers and others engaged in the foreign exchange market, that hedging facilities would be completely inadequate or that the cost of forward cover would be prohibitive. Both arguments seek to deny the economic principle that a competitive system will tend to provide any good or service demanded, at a price that yields no more than a fair profit. They derive, moreover, from the experience of recent crises under the fixed rate system. When exchange rates are rigidly fixed by official intervention, businessmen normally do not consider the cost of forward cover worth their while; but when everyone expects the currency to be devalued, everyone seeks to hedge his risks by selling it forward, the normal balancing of forward demands and supplies ceases to prevail, the forward rate drops to a heavy discount, and the cost of forward cover becomes "prohibitive." Under a Hexible exchange rate system, where the spot rate is also free to move, arbitrage between the spot and forward markets, as well as speculation, would ensure that the expectation of depreciation was reflected in depreciation of the spot as well as the forward rate, and hence tend to keep the cost of forward cover within reasonable bounds.

Incentive to "Destabilizing Speculation" - A further argument under the heading of uncertainty is that it will encourage "destabilizing speculation." The historical record provides no convincing supporting evidence for this claim, unless "destabilizing speculation" is erroneously defined to include any speculation against an officially pegged exchange rate, regardless of how unrealistic that rate was under the prevailing circumstances. A counter-consideration is that speculators who engage in genuinely destablilizing speculation - that is, whose speculations move the exchange rate away from rather than towards its equilibrium level - will consistently lose money, because they will consistently be buying when the rate is "high" and selling when it is "low" by comparison with its equilibrium value; this consideration does not however exclude the possibility that clever professional speculators may be able to profit by leading amateur speculators into destabilizing speculation, buying near the trough and selling near the peak, the amateurs losses being borne out of their (or their shareholders') regular income. A further counterconsideration is that under flexible rates, speculation will itself move the spot rate, thus generating uncertainty in the minds of the speculators about the magnitude of prospective profits, which will depend on the relation between the spot rate and the expected future rate of exchange, neither of which will be fixed and independent of the magnitude of the speculators' transactions. By contrast, the adjustable peg system gives the speculator a "one-way option": in circumstances giving rise to speculation on a change in the rate, the rate can only move one way if it moves at all, and if it moves it is certain to be changed by a significant amount - and possibly by more, the stronger is the speculation on a change. The fixed exchange rate system courts "destabilizing speculation," in the economically incorrect sense of speculation against the permanence of the official parity, by providing this one-way option; in so doing it places the monetary authorities in the position of speculating on their own ability to maintain the parity. It is obviously fallacious to assume that private speculators would speculate in the same way and on the same scale under the flexible rate system, which offers them no such easy mark to speculate against. 


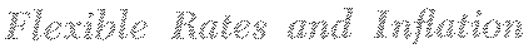

The argument that the flexible exchange rate system would promote inflation comes in two major versions. The first is that under the flexible rate system governments would no longer be subject to the "discipline" against inflationary policies exerted by the fixity of the exchange rate. This argument in large part reflects circular reasoning on the part of the fixed rate exponents: discipline against inflationary policies, if necessary for international reasons, is necessary only because rates are fixed, and domestic inflation both leads to balance-of-payments problems and imposes inflation on other countries. Neither consequence would follow under the flexible exchange rate system. Apart from its external repercussions, inflation may be regarded as undesirable for domestic reasons; but the fixed rate system imposes, not the need to maintain domestic price stability, but the obligation to conform to the average world trend of prices, which may be either inflationary or deflationary rather than stable. ${ }^{2}$ Moreover, under the adjustable peg system actually existing, countries can evade the discipline against excessively rapid inflation by drawing down reserves and borrowing, by imposing restrictions on international trade and payments, and in the last resort by devaluing their currencies. The record since the Second World War speaks poorly for the anti-inflationary discipline of fixed exchange rates. The reason is that the signal to governments of the need for anti-inflationary discipline comes through a loss of exchange reserves, the implications of which are understood by only a few and can be disregarded or temporized with until a crisis descends - and the crisis justifies all sorts of policy expedients other than the domestic deflation which the logic of adjustment under the fixed rate system demands. Under a flexible rate system, the consequences of inflationary governmental policies would be much more readily apparent to the general population, in the form of a declining foreign value of the currency and an upward trend in domestic prices; and proper policies to correct the situation, if it were desired to correct it, could be argued about in freedom from an atmosphere of crisis.

The second argument to the effect that a flexible exchange rate would be "inflationary" asserts that any random depreciation would, by raising the cost of living, provoke wage and price increases that would

\footnotetext{
${ }^{2} \mathrm{~A}$ good example is Germany, which is suffering from balanceof-payments surpluses, because its price increases have been less than the average world trend.
}

make the initially temporarily lower foreign value of the currency the new equilibrium exchange rate. This argument clearly derives from confusion of a flexible with a fixed exchange rate. It is under a fixed exchange rate that wages and prices are determined in the expectation of constancy of the domestic currency cost of foreign exchange, and that abrupt devaluations occur that are substantial enough in their effects on the prices of imports and of exportable goods to require compensatory revision of wage bargains and price-determination calculations. Under a flexible rate system, exchange rate adjustments would occur gradually, and would be less likely to require drastic revisions of wage- and price-setting decisions, especially as any general trend of the exchange rate and prices would tend to be taken into account in the accompanying calculations of unions and employers. Apart from this, it is erroneous to assume that increases in the cost of living inevitably produce fully compensatory wage increases; while such increases in the cost of living will be advanced as part of the workers' case for higher wages, whether they will in fact result in compensatory or in less than compensatory actual wage increases will depend on the economic climate set by the government's fiscal and monetary policies. It is conceivable that a government pledged to maintain full employment would maintain an economic climate in which any money wage increase workers chose to press for would be sanctioned by sufficient inflation of monetary demand and the money supply to prevent it from resulting in an increase in unemployment. But in that case there would be no restraint on wage increases and hence on wage and price inflation, unless the government somehow had arrived at an understanding with the unions and employers that only wage increases compensatory of previous cost of living increases (or justified by increases in productivity) would be sanctioned by easier fiscal and monetary policy. That is an improbable situation, given the difficulties that governments have encountered with establishing and implementing an "incomes policy" under the fixed rate system; and it is under the fixed rate system, not the flexible rate system, that governments have a strong incentive to insist on relating increases in money incomes to increases in productivity and hence are led on equity grounds to make exceptions for increases in the cost of living. It should be noted in conclusion that one version of the argument under discussion, which reasons from the allegation of a persistent tendency to cost-push inflation to the prediction of a persistent tendency towards depreciation 
of the currency, must be fallacious: it is logically impossible for all currencies to be persistently depreciating against each other.

\section{Contemporary Proposals for Greater Exchange Rate Flexibility}

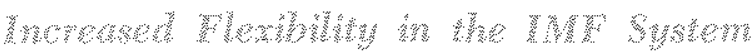

The extreme difficulties that have been encountered in recent years in achieving appropriate adjustments of the parity values of certain major currencies within the present "adjustable peg" system of fixed exchange rates, as exemplified particularly in the prolonged agony of sterling from 1964 to 1967 and the failure of the "Bonn crisis" of November 1968 to induce the German and French governments to accept the revaluations of the franc and the mark agreed on as necessary by the officials and experts concerned with the international monetary system, have generated serious interest, especially in the United States Administration, in proposals for reforming the present I M F system so as to provide for more flexibility of exchange rates. It has been realized that under the present system, a devaluation has become a symbol of political defeat by, and a revaluation (appreciation) a symbol of political surrender to, other countries, both of which the government in power will resist to the last ditch; and that this political symbolism prevents adjustments of exchange rates that otherwise would or should be accepted as necessary to the proper functioning of the international monetary system. The aim therefore is to reduce or remove the political element in exchange rate adjustment under the present system, by changing the system so as to allow the anonymous competitive foreign exchange market to make automatic adjustments of exchange rates within a limited range.

The two major proposals to this end are the "wider band" proposal and the "crawling peg" proposal. Under the "wider band" proposal, the present freedom of countries to allow the market value of their currencies to fluctuate within one per cent (in practice usually less) of their par values would be extended to permit variation within a much wider range (usually put at five per cent for argument's sake). Under the "crawling peg" proposal, daily fluctuations about the par value would be confined within the present or somewhat wider limits, but the parity itself would be determined by a moving average of the rates actually set in the market over some fixed period of the immediate past, and so would gradually adjust itself upwards or downwards over time to the mar- ket pressures of excess supply of or excess demand for the currency (pressures for depreciation or appreciation, rise or fall in the par value, respectively).

Both of these proposals, while welcomed by advocates of the flexible exchange rate system to the extent that they recognize the case for flexible rates and the virtues of market determination as contrasted with political determination of exchange rates, are subject to the criticism that they accept the principle of market determination of exchange rates only within politically predetermined limits, and hence abjure use of the prime virtue of the competitive market, its capacity to absorb and deal with unexpected economic developments." The criticism is that either economic developments will not be such as to make the equilibrium exchange rate fall outside the permitted range of variation, in which case the restriction on the permitted range of variation will prove unnecessary, or economic change will require more change in the exchange rate than the remaining restriction on exchange rate variation will permit, in which case the problems of the present system will recur (though obviously less frequently). Specifically, sooner or later the exchange rate of a major country will reach the limit of permitted variation, and the speculation-generating possibility will arise that the par value of that currency will have to be changed by a finite and substantial percentage, as a result of lack of sufficient international reserves for the monetary authorities of the country concerned to defend the par value of the currency.

In this respect, there is a crucial difference between the wider band proposal and the crawling peg proposal. The wider band system would provide only a once-for-all increase in the degree of freedom of exchange rates to adjust to changing circumstances. A country that followed a more inflationary policy than other nations would find its exchange rate drifting towards the ceiling on its par value, and a country that followed a less inflationary policy than its neighbours would find its exchange rate sinking towards the floor under its par value. Once one or the other fixed limit was reached, the country would to all intents and purposes be back on a rigidly fixed exchange rate. The crawling peg proposal, on the other hand, would permit a country's policy, with respect to the relative rate of inflation it preferred, to diverge permanently from that of its neighbours, but only within the limits set by the permitted range

SIt is quite likely that a crawling peg would not have provided an equilibrium exchange rate in France after the events of May 1968. 
of daily variation about the daily par value and the period of averaging of past actual exchange rates specified for the determination of the par value itself. For those persuaded of the case for flexible exchange rates, the crawling peg is thus definitely to be preferred. The only question is the empirical one of whether the permitted degree of exchange rate flexibility would be adequate to eliminate the likelihood in practice of a situation in which an exchange rate was so far out of equilibrium as to make it impossible for the monetary authorities to finance the period of adjustment of the rate to equilibrium by use of their international reserves and international borrowing power. This is an extremely difficult empirical question, because it involves not only the likely magnitude of disequilibrating disturbances in relation to the permitted degree of exchange rate adjustment, but also the effects of the knowledge by government of the availability of increased possibilities of exchange tate flexibility on the speed of governmental policy response to disequilibrating developments, and the effects of the knowledge by private speculators that the effects on the exchange rate of current speculation will determine the range within which the ex" change rate will be in the future, on the assumption that the crawling peg formula continues to hold.

Evaluation of how both the wider band and the crawling peg proposals should work in practice requires a great deal of empirical study, which has not yet been carried out on any adequate scale. In the meantime, those persuaded of the case for flexible exchange rates would probably be better advised to advocate experimentation with limited rate flexibility, in the hope that the results will dispel the fears of the supporters of the fixed rate system, than to emphasize the dangers inherent in the residual fixity of exchange rates under either of the contemporary popular proposals for increasing the flexibility of rates under the existing fixed rate systems.

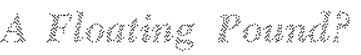

The argument of the preceding sections strongly suggests the advisability of a change in British exchange rate policy from a fixed exchange rate to a market-determined flexible exchange rate. The main arguments for this change are that a flexible exchange rate would free British economic policy from the apparent necessity to pursue otherwise irrational and difficult policy objectives for the sake of improving the balance of payments, and that it would release the country from the vicious circle of "stop-go" policies of control of aggregate demand.
A flexible exchange rate is not of course a panacea; it simply provides an extra degree of freedom, by removing the balance-of-payments constraints on policy formation. In so doing, it does not and cannot remove the constraint on policy imposed by the limitation of total available national resources and the consequent necessity of choice among available alternatives; it simply brings this choice, rather than the external consequences of choices made, to the forefront of the policy debate.

The British economy is at present riddled with inefficiencies consequential on, and politically justified by, decisions based on the aim of improving the balance of payments. In this connection, one can cite as only some among many examples the heavy protection of domestic agriculture, the protection of domestic fuel resources by the taxation of imported oil, the subsidization of manufacturing as against the service trades through the Selective Employment Tax, and various other subsidies to manufacturing effected through tax credits. One can also cite the politically arduous effort to implement an incomes policy, which amounts to an effort to avoid by political pressure on individual wage- and price-setting decisions the need for an adjustment that would be effected automatically by a flexible exchange rate. A flexible exchange rate would make an incomes policy unnecessary. It would also permit policy towards industry, argiculture, and the service trades to concentrate on the achievement of greater economic efficiency, without the biases imparted by the basically economically irrelevant objectives of increasing exports or substituting for imports.

The adoption of flexible exchange rates would also make unnecessary, or at least less harmful, the dis. ruptive cycle of "stop-go" aggregate demand policies which has characterized British economic policy for many years. British Governments are under a persistently strong incentive to try to break out of the limitations of available resources and relatively slow economic growth by policies of demand expansion. This incentive is reinforced, before elections, by the temptation to expand demand in order to win votes, in the knowledge that international reserves and in ternational borrowing power can be drawn down to finance the purchase of votes without the electorate knowing that it is being bribed with its own money until after the election the successful party is obliged to clean up the mess so created by introducing deflationary policies, with political safety if it is a returned government, and with political embarrassment if it is an opposition party newly come to power. If the 
country were on a Alexible exchange rate, the generation of the "political cycle" would be inhibited by the fact that the effort to buy votes by pre-election inflationary policies would soon be reflected in a depreciation of the exchange rate and a rise in the cost of living. Even if this were avoided by use of the Government's control of the country's international reserves and borrowing powers to stabilize the exchange rate, a newly elected Government of either complexion would not be faced with the absolute necessity of introducing deflationary economic policies to restore its international reserves. It could instead allow the exchange rate to depreciate while it made up its mind what to do. Apart from the question of winning elections, Governments that be lieved in demand expansion as a means of promoting growth could pursue this policy a outrance, without being forced to reverse it by a balance-of-payments crisis, so long as they and the public were prepared to accept the consequential depreciation of the currency; Governments that believed instead in other kinds of policies would have to argue for and defend them on their merits, without being able to pass them off as imposed on the country by the need to secure equilibrium in the balance of payments.

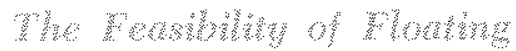

While these and other elements of the case for a floating pound have frequently been recognized and advocated, it has been much more common to argue that a flexible exchange rate for sterling is "impos" sible," either because the position of sterling as an international reserve currency precludes it, or because the International Monetary Fund would not permit it. But most of the arguments for the presumed international importance of a fixed international value of sterling have been rendered irrelevant by the deterioration of sterling's international position subsequent to the 1967 devaluation, and in particular by the Basle Facility and the sterling area agreements concluded in the autumn of 1968, which by giving a gold guarantee on most of the overseas sterling area holdings of sterling have freed the British authorities to change the foreign exchange value of sterling without fear of recrimination from its official holders. Moreover, the relative decline in the international role of sterling, and in the relative importance of Britain in world trade, finance and investments that have characterized the post-war period, has made it both possible and necessary to think of Britain as a relatively small component of the international monetary system, more a country whose difficulties require special treatment than a lynch-pin of the system, the fixed value of whose currency must be supported by other countries in the interests of survival of the system as a whole.

Under the present circumstances, adoption of a floating exchange rate for the pound would constitute, not a definitive reversal of the essential nature of the I M. F system of predominantly fixed exchange rates, but recognition of and accommodation to a situation in which the chronic weakness of the pound is a major source of tension within the established system. The International Monetary Fund is commonly depicted in Britain as an ignorantly dogmatic but politically powerful opponent of sensible changes that have the drawback of conflicting with the ideology written into its Charter. But there is no reason to believe that the Fund, as the dispassionate administrator of an international monetary system established nearly a quarter of a century ago to serve the needs of the international economy, is insensitive to the tensions of the contemporary situation and blindly hostile to reforms that would permit the system as a whole to survive and function more effectively.

This article is available as Reprint No, 41 . 